\title{
White Slave Traffic in International Law
}

\author{
Jean Allain*
}

The evolution in the legal regime governing human trafficking can be separated neatly into three eras: the Pre-League of Nations, the League of Nations, and the United Nations. This study considers the first of these eras; in the development of the Pre-League of Nations legal regime surrounding the 'White Slave Traffic'. While that very term was considered troublesome at the time; today it is downright offensive: clearly objectionable on a number of grounds, most obviously its overt racism and its equating of the slave trade with prostitution. ${ }^{1}$ Despite this, the regime of White Slave Traffic is the 1904 International Agreement for the Suppression of the White Slave Traffic and the 1910 International Convention for the Suppression of the White Slave Traffic; and remains fundamental to understanding the evolution of what is today understood as human trafficking generally, and more specifically, trafficking related to sexual exploitation; and the dynamics which shaped its contemporary contours and the language used to define it.

The era of the White Slave Traffic, spanning the first decade of the Twentieth Century, is a reflection of a time when the limited engagements of the Nineteenth Century Congress of Europe gave way to a growing willingness by European States to cooperate, multilaterally, through negotiating international agreements (though these were, in effect, largely European in scope). Both the 1904 International Agreement and the 1910 International Convention were negotiated in substance at the 1902 International Conference on the White Slave Traffic. However, due to the nature of international law at the time, the showcase of the negotiations at 1902 Conference, its Draft Convention, was left to linger for eight years before a hastily convened diplomatic conference was able to iron out the legal niceties and bring that Convention into force. In the interim, a negotiated afterthought, the Draft Arrangement meant to give administrative effect to the Convention was, in fact, brought into force as the 1904 International Agreement for the Suppression of the White Slave Traffic.

The negotiations of these white slave traffic instruments provides a number interesting considerations which remain central to contemporary human trafficking including: the appearance, for the first time, of various terms which find their way into the current definition of trafficking; but also whether trafficking is meant to suppress sexual exploitation or prostitution; and the internal/external dichotomy of trafficking. This study considers the records of those two international conferences on the white slave traffic to better understand the early years of the regime which today is manifest in the 2000 Palermo Protocol and the 2005 Council of Europe Convention dealing with human trafficking. In so doing, it moves away from much of the ahistorical considerations endued throughout contemporary legal scholarship in the area human trafficking; providing context and a better sense of what was sought to be achieved by those who negotiated the first international agreements to address, in the language of the times: the white slave traffic.

\footnotetext{
*of the Editorial Board.

Note: unless otherwise indicated, where reference to a direct citation is in French, the translation has been made by the author.

The author wishes to acknowledge the United Kingdom Arts \& Humanities Research Council, and its funding under the Care for the Future scheme, which allow for the research for this article to be undertake at the Diplomatic Archives of the French Foreign Ministry, through its Antislavery Usable Past Large Grant.

1 The term 'White Slave Traffic' is often placed in quotation marks reflecting a disquiet amongst scholars. Yet, much like the phrase 'general principles of law recognized by civilised nations', 'White Slave Traffic' is a window onto a very different world of the early $20^{\text {th }}$ Century, one dominated by a Euro-centrism of overt racism, at the height of its colonial conquest. With this in mind, from hereon in, the protection of the quotation marks is dispensed with.
} 


\section{The White Slave Traffic}

The basis of what is today recognised in international law as human trafficking is an account which is only now emerging from the archives and the pens of historians. The history of the white slave traffic is grounded in the issue of venereal disease. It found its origins in a Victorian paternalism of the late $19^{\text {th }}$ Century which sought to control women in the face of communicable diseases which were playing havoc on troops destined to engage in Europe's colonial project. Judith Walkowitz argues that genesis of the white slave traffic was a reaction to the founding, in the United Kingdom in 1869, of the Ladies National Association which sought to repeal the various Contagious Disease Acts of the 1860s as being unconstitutional, discriminatory, and promoting male vice; while subjecting women to "degrading internal examinations". 2 Such talk of repeal put the expansionist project of Empire at risk and was countered by a moral panic in regard to children and prostitution.

At the international level the issue fell to attempts to control women, during the Age of Steam, who sought to accompany armies in the field, as mass prostitution was "organized to serve the needs of colonial troops". ${ }^{3}$ In 1873, the International Medical Congress called for an end to State regulation of brothels and prostitution; but this was understood to be a matter of domestic jurisdictions. ${ }^{4}$ What made the issue an international one was the scandal which broke in relation to Belgium in 1880 with the publication, in London, of Alfred Dyer's The European Slave Trade in English Girls. The scandal had at its core, the so-called 'French system' of legal sex work requiring the mandatory registration of prostitutes for "reasons of public health and public order", and "strongly encouraged" the establishment of brothels. ${ }^{5}$ The scandal turned on the revelation that girls under the age of twenty-one from the United Kingdom had procured false documents which had been accepted by the police despite "a discrepancy between the declared age and the age they appeared to be". ${ }^{2}$ This in the context of State sanctioned brothels and the regulation of prostitution being the norm throughout late $19^{\text {th }}$ Century continental Europe.

The momentum started in Brussels in 1880 would, in time, galvanise public opinion, with the exposé of child prostitution in London by W.T. Stead in 1885 leading directly to the creation of the National Vigilance Society; which, in turn, would be the conduit from a nongovernmental to an official, governmental, response to the white slave traffic through the Vigilance Society's 1898 resolution "to open definite measures for its mitigation - if possible its suppression". ${ }^{7}$ To that end, the Society sent its Secretary, William Alexander Coote, on mission to Copenhagen, Berlin, Brussels, Paris, Stockholm, St. Petersburg, and The Hague, where, it is said, the "Governments of these different countries were found [...] to be fully alive to the importance of the question". To that end, a number of States were prepared to send official delegations to London for the planned first International Congress on the White Slave

\footnotetext{
Judith Walkowitz, Prostitution and Victorian Society: Women, Class, and the State, 1980, p. 2.

Laura Reanda, "Prostitution as a Human Rights Question: Problems and Prospects of United Nations Action" (1991) 13 Human Rights Quarterly 207; also see Nora Demleitner, "Forced Prostitution; Naming an International Offense" (1994-1995) 18 Fordham International Law Journal 163.

4 Vern Bullough and Bonnie Bullough, Women and Prostitution: A Social History, 1987, p. 263.

${ }^{5}$ See generally Jean-Michel Chaumont, Le mythe de la traite des blances, 2009. Chaumont places the origins of campaigns against the White Slave Traffic as transpiring in Belgium in 1880, then in the United Kingdom in 1885 , in France in 1902, and in the United States in 1907. See Jean-Michel Chaumont, and Christine Machiels (eds.), Du sordide au mythe: L'affaire de la traite des blanches (Bruxelles, 1880), p. 235, n. 849.

6 Jean-Michel Chaumont, “The White Slave Trade Affair (1880-1881): A Scandal specific to Brussels?”, (2011) 46 Brussels Studies 2-4.

"Memorandum on the Origin and Evolution of the Movement for the Suppression of the White Slave Traffic", Annex 3, Correspondence respecting the International Conference on the White Slave Traffic, held in Paris, October 1906, House of Commons Parliamentary Papers (United Kingdom), Miscellaneous No.2 (1907), Cd. 3453 , p. 15.
} 
Trade in 1899 , to be hosted by the National Vigilance Society. However, the British Foreign Office demurred, "pointing out that to give an official character to the Congress might prove embarrassing". "While the British Foreign Secretary, Lord Salisbury, in correspondence with his European counterparts, promised "the most careful attention" would be paid to "evidence collected and the conclusions arrived at" during the 1899 Congress, these diplomatic platitudes would, in fact, become a reality in the hands of the French Foreign Ministry as it would convoke a diplomatic conference three years later, in 1902.

For its part, the 1899 International Congress on the White Slave Trade, held in London, had put forward the following, with a wish that "an agreement be established between the most interested Governments:

1. To punish, and as far as possible by penalties of equal degree, the procuring of women and girls by violence, fraud, abuse of authority, or any other method of constraint, to give themselves to debauchery, or to continue in it; and in cases were persons are accused of this crime: -

2. To undertake simultaneous investigations into the crime when the facts which constitute it occur in different countries.

3. To prevent any conflict of jurisdiction by determining the proper place of trial.

4. To provide by International Treaties for the extradition of the accused. ${ }^{9}$

The Congress had "formulated these propositions after having recognised that the causes of impunity of this odious traffic are the absence of a specific offense and penalty, the difference in legislation applicable to such infraction of the law, and most importantly, the impossible situation which States find themselves in without extradition procedures to deal with authors of acts committed outside their own territory". ${ }^{10}$

During the 1899 Congress a body was created to oversee the execution of its various resolutions, including inviting a State to take the lead in calling an international diplomatic conference. The French Government, having been approached, took up that invitation and convened the International Conference on the White Slave Traffic from 15 to 25 July 1902; setting out the following "questions which were to be the object of deliberation at the Conference"; these having been based on the four points, noted above, as set out at the 1899 London Congress:

\section{I.-Penal Measures.}

To include in the penal legislation of countries, whose laws contain insufficient provision for dealing with them, the following offences:-

$$
\text { (A.) - Girls under Age. }
$$

8 Annex 3, "Memorandum on the Origin and Evolution of the Movement for the Suppression of the White Slave Traffic", Correspondence respecting the International Conference on the White Slave Traffic, held in Paris, October 1906, House of Commons Parliamentary Papers (United Kingdom), Miscellaneous No.2 (1907), Cd. 3453, p. 15.

In opening the 1902 International Conference on the White Slave Traffic, the French Foreign Minister, Delcassé spoke of this possibility of embarrassment, saying that those deliberation at the 1899 Congress where "people who allowed their hearts to guide their intellect". See Procès-Verbaux des Séances, Première Séance, Ministère des Affaires Étrangères, Conférence Internationale pour la Répression de la Traite des Blanches, Documents Diplomatiques, 1902, p. 58.

9 National Vigilance Association, Transactions of the International Congress on the White Slave Trade, held in Lond on 21-23 of June, 1899, p. 17.

10 Document Préliminaires, Ministère des Affaires Étrangères, Conférence Internationale pour la Répression de la Traite des Blanches, Documents Diplomatiques, 1902, p. 13. 
1. Procuring or kidnapping of girls with a view to prostitution: admission to, or detention in, houses or places of ill-fame.

Penalties to be fixed.

2. The increase of penalties if the offence is accompanied by violence, threats, fraud, abuse of authority, or any other means of compulsion.

$$
\text { (B.)-Women. }
$$

Procuring or kidnapping with a view to prostitution, admission or detention in houses of ill-fame or brothels, when the proceedings are accompanied by violence, threats, fraud, abuse of authority, or any other means of compulsion.

Penalties to be fixed.

\section{II.-The Conclusion of an International Convention dealing with the following points:}

1. Competency as regards prosecutions;

2. The extradition of offenders and their accomplices;

3. The execution with the least possible delay of warrants of arrest and letters of request;

4. The supervision of the departure and arrival of persons suspected of the denounced practices, and of their victims; the transmission of information to the Governments concerned respecting the domicile of the latter, and their repatriation;

5. The instructions to be given to the Diplomatic or Consular Agents of the various foreign Governments. ${ }^{11}$

\section{The 1902 International Conference on the White Slave Traffic}

While the diplomatic gathering was billed an 'International Conference', it was very much a European affair (and - it must be said - an affair of the kingdoms of Europe, save Switzerland, and their aristocratic representatives), with the participation of Austria, Belgium, Denmark, France, Hungary, Italy, Germany, Norway, Portugal, Russia, Spain, Sweden, Switzerland, The Netherlands, the United Kingdom. The only outlier was Brazil. For the noted French jurist, Louis Renault, commenting on the Conference, he took no heed of the divide of Atlantic Ocean, instead noting that the participants included "all European States except for the Balkan States". 12

11 See "Questions Submitted to the Consideration of the Conference", Correspondence respecting the International Conference on the 'White Slave Traffic', held in Paris, July 1902, House of Commons Parliamentary Papers (United Kingdom), Miscellaneous No. 3 (1905), Cd. 2667, p. 6.

Note also a Report prepared by the French Delegation with regard to the Questions Submitted to the Consideration of the Conference; and the Response by the German Government appended hereto: Document Préliminaires, Ministère des Affaires Étrangères, Conférence Internationale pour la Répression de la Traite des Blanches, Documents Diplomatiques, 1902, pp. 16-45; which considered the legislation, administrative measures, and measure related to jurisdiction and procedure, in relation to the State participating in the Conference.

12 Louis Renault, "La 'Traite des Blanches' et la Conférence de Paris au point de vue du droit international", (1902) 9 La Revue Genéral de droit international public 499.

Note that for the Rapporteur for the Legislative Commission convened by the Conference, Mr FerdinandDreyfus of the French Delegation, the negotiation sought to reach agreement amongst "Civilised Nations". See Commission Législative, Rapport présenté par M. Ferdinand-Dreyfus, Annexe au Procès-Verbal de la Quatrième Séance, Ministère des Affaires Étrangères, Conférence Internationale pour la Répression de la Traite des Blanches, Documents Diplomatiques, 1902, p. 125.

From today's perspective, the absence of the United States of America is of note, especially in the context of being in the midst of addressing its own white slave traffic. At the federal level, this would transpire through the so-called 'Mann Act', the White Slave Traffic Act of 1910. See generally: Jessica Pliley, Policing Sexuality: The Mann Act and the Making of the FBI, 2014. However, it should be recalled that there was, at the time, a current 
During the first sessions of the 1902 International Conference on the White Slave Traffic it was decided that a record would be made of the discussion during the plenary sessions of the Conference; while the four Commissions (re: sub-committees of the Conference) formed related to legislation, administration, and jurisdiction and procedural matters; as well as the Drafting Commission - would provide reports of their deliberations. ${ }^{13}$ When, during the third session, the commissions provided their conclusions - though not their Reports, the fundamental question of what the Conference would be proposing to their Governments was broached. While the Legislative Commission set out "indications and recommendations" to be made to the Governments, the very active Swiss Delegate, Mr. Lardy, was of the opinion that the Conference "must present to its Governments a draft of a Convention which it recommends for adoption"; deeming that it would be a "veritable failure if the work of the Conference ended with only expressions of non-binding wishes". ${ }^{14}$ While this was not agreed to right away, it foreshadowed the outcome of the Conference. Lardy spelled out the benefits of putting forward a draft instrument, noting that States could either "immediately approve or reject or even delay signing and ratifying"; the latter possibilities would give certain States the opportunity to modify their domestic legislation in order to bring it into line with the requirements of the proposed instrument. ${ }^{15}$

When the Plenary of the Conference turned to consider the substance of the Reports of the various commissions, it was clear that the Report of the Legislative Commission held the most interest, as it looked to make up the bulk of the envisioned draft convention. Starting off the substantive deliberations was what was deemed a "preliminary question" by the Italian Delegate, the Marquis Paulucci de Calboli, who noted that:

the words 'white slave traffic' appeared to be improper. The word 'white' does not apply to the generality of women, yellow, black etc. As for 'slave traffic' this also indicated the notions of import and export, characteristics which do not always appear in the violation in question which, as a result of the discussion on which the delegates are unanimous, are not aiming to deal only with an international violation. ${ }^{16}$

Although not seriously engaged with, the link between the white slave traffic and the trade of enslaved Africans was broached was broached in an earlier Session by Mr. Macare of The Netherlands, who drew the attention of the Conference to a provision of Dutch law related to the slave trade (traite des noirs) "which seemed to us offered a formula which we are looking for to suppress the white slave traffic" (traite des blanches). ${ }^{17}$

As for the French jurist, Renault, he stated that he also considered the term 'white slave traffic' to be:

very unsatisfactory and undertook, on behalf of the Drafting Commission, to not use it in any text which has a legislative or conventional character. That said, that this designation was known and accepted appeared to him to require its absolute prescription: it could be included in the preamble of a draft convention. We have

of American isolationist foreign policy, which in this era would preclude it from joining this Conference and, it might be added, the League of Nations, despite being the brainchild of US President Woodrow Wilson.

13 Procès-Verbaux des Séances, Première Séance, at p. 61, and Deuxième Séance, at p. 84; in Ministère des Affaires Étrangères, Conférence Internationale pour la Répression de la Traite des Blanches, Documents Diplomatiques, 1902, p. 125.

14 Procès-Verbaux des Séances, Troisième Séance, Ministère des Affaires Étrangères, Conférence Internationale pour la Répression de la Traite des Blanches, Documents Diplomatiques, 1902, p. 105.

15 Id.

16 Id., p. 111.

17 Procès-Verbaux des Séances, Deuxième Séance, Ministère des Affaires Étrangères, Conférence Internationale pour la Répression de la Traite des Blanches, Documents Diplomatiques, 1902, p. 76.

Macaré stated somewhat flippantly that "all we have to do is change a word". That change, which was never given consideration, was from "whoever undertakes commerce in slaves for his own benefit", to "whoever undertakes commerce of women without their knowledge for his own benefit", id. Emphasis added. 
spoken a lot of the Congress on the 'White Slave Trade'. To completely abandon this established expression would not be without its inconveniences. ${ }^{18}$

When presenting the Report of the Drafting Commission, Renault expanded on the thinking noted above, stating that the Commission "preserved both in the title and in the preamble of the Convention, the well-established expression 'White Slave Traffic' because of its significance, because it indicates the traffic which is to be suppressed in a manner which everyone will understand, and because it would be difficult to find an alternative". He followed this by insisting that: "We do not, however, pretend that it is not in itself open to criticism, and we have avoided using it in the actual official instrument". ${ }^{19}$

When presenting his thoughts on the Conference later that year in La Revue genéral de droit international public, Renault was less guarded, saying that term white slave traffic "appears to be the title of a melodrama or a popular romance rather than a legislative or diplomatic text". ${ }^{20}$ And yet Renault comes around, first indicating that he thought the "expression is rather ringing, destined to make an impression on the general public, though singularly exaggerated", though he had come to the realisation, "after serious enquires, that the expression, good or bad in and of itself, corresponded to a real wrong and that the biggest efforts were necessary if one wanted to diminish or simply try to stop its growth". ${ }^{21}$

While the racialised element of the term 'white' slave traffic was not happenstance, and was evident throughout the deliberation of the 1902 International Conference; it was made most evident in the Report of the Legislative Commission which set out that the harm which was sought to be addressed was only applicable to women of European stock: "The victim procured in a northern country, conveyed across a central country, has been delivered up in a southern country". ${ }^{22}$ In assessing the 1902 Conference, Renault's benevolent thoughts demonstrate the undercurrent of racialised thinking which permeated the era, as he considered that "the draft developed between European delegates naturally was aimed at the White Slave trade, but it is worth remarking that the trade is not only fixed on women of a certain colour". In and of themselves, these sentiments are not too problematic, however, when he carries his thoughts into the following sentence, they are overt: "In that, a not inconsequential traffic in yellow women is practiced between Japan and different countries". ${ }^{23}$

Having undertaken a comparative consideration of legislation in force in the Delegations' home States, the Legislative Commission provided a definition of what constitutes white slave traffic and, in so doing, would provide the first, embryonic, definition of what would later become the established definition of trafficking in persons within the 2000 Protocol to Prevent,

18 Procès-Verbaux des Séances, Troisième Séance, Ministère des Affaires Étrangères, Conférence Internationale pour la Répression de la Traite des Blanches, Documents Diplomatiques, 1902, p. 112.

19 Commission de Rédaction, Rapport présenté par M. Louis Renault, Annexe au Procès-Verbal de la Septrième Séance, Ministère des Affaires Étrangères, Conférence Internationale pour la Répression de la Traite des Blanches, Documents Diplomatiques, 1902, p. 181; English translation from "Questions Submitted to the Consideration of the Conference", Correspondence respecting the International Conference on the "White Slave Traffic', held in Paris, July 1902, House of Commons Parliamentary Papers (United Kingdom), Miscellaneous No. 3 (1905), Cd. 2667, p. 33.

20 Louis Renault, "La 'Traite des Blanches' et la Conférence de Paris au point de vue du droit international", (1902) 9 La Revue Genéral de droit international public 497.

21 Id., p. 497.

22 See Commission Législative, Rapport présenté par M. Ferdinand-Dreyfus, Annexe au Procès-Verbal de la Quatrième Séance, Ministère des Affaires Étrangères, Conférence Internationale pour la Répression de la Traite des Blanches, Documents Diplomatiques, 1902, p. 123; as translated in to English in: Correspondence respecting the International Conference on the 'White Slave Traffic', held in Paris, July 1902, House of Commons Parliamentary Papers (United Kingdom), Miscellaneous No. 3 (1905), Cd. 2667, p. 9.

23 Louis Renault, "La 'Traite des Blanches' et la Conférence de Paris au point de vue du droit international", (1902) 9 La Revue Genéral de droit international public 508. Emphasis in the original. 
Suppress and Punish Trafficking in Persons, Especially Women and Children. The Report of the Legislative Commission believed that even "those States which have the most rigorous laws may find certain new constitutive elements, such as definitions which are more adequate to the stated purpose". To that end, and "with a view of affording a better definition of the new offence", the Legislative Commission set out the constitutive elements of the offence of white slave traffic:

it is committed by any person who, to satisfy the passions of another, has procured, enticed, or led astray a woman or girl, with immoral intent.

The Report went on to consider these elements, stating that: "to 'procure' is to invite or lead the woman or girl to become a prostitute; to 'entice' is to take her away with or persuade her to follow; to 'lead astray' is to remove her illegally from her surroundings". The Report continued by noting, more generally, that:

The offence is characterized by its continuity; the successive steps which it may entail take place either within the frontiers of one country alone or in several countries. There is no unity of place. This criminal traffic is international: the human body is traded in and treated as merchandize; the traffickers in it have their agencies, their depots, their correspondents, their export offices, and even their code. To reach there; the hand of justice must fall on them wherever an offence is committed. ${ }^{24}$

Having established the constitutive elements of the crime of white slave traffic, the Legislative Committee sought to make the distinction of the offence itself, as between women and the girl child. As regards girls, "the crime exits even with consent; as for a women, the crime exists only where violence or threats have been visited upon her, or where she has been deceived". ${ }^{25}$ The Legislative Commission thus proposed the following:

1. Severely punished will be any person who, to satisfy the passions of another, shall have procured, enticed or led astray, even with her consent, an under-age girl, with immoral intent.

2. Equally will be punished any person who by violence, threats, abuse of authority, compulsion or fraud will have procured, enticed, or led astray a woman or a girl over age, with immoral intent. ${ }^{26}$

For those familiar with the contemporary definition of human trafficking, the terms 'abuse of authority', 'fraud', 'threats' and 'violence' will stand out, as they have been maintained throughout the process from 1902 to the contemporary definition of the $21^{\text {st }}$ Century. ${ }^{27}$ And it

24 See Commission Législative, Rapport présenté par M. Ferdinand-Dreyfus, Annexe au Procès-Verbal de la Quatrième Séance, Ministère des Affaires Étrangères, Conférence Internationale pour la Répression de la Traite des Blanches, Documents Diplomatiques, 1902, p. 122; as translated in to English in: Correspondence respecting the International Conference on the 'White Slave Traffic', held in Paris, July 1902, House of Commons Parliamentary Papers (United Kingdom), Miscellaneous No. 3 (1905), Cd. 2667, p. 9.

${ }^{25}$ Commission Législative, Rapport présenté par M. Ferdinand-Dreyfus, Annexe au Procès-Verbal de la Quatrième Séance, Ministère des Affaires Étrangères, Conférence Internationale pour la Répression de la Traite des Blanches, Documents Diplomatiques, 1902, p. 123.

26 Id., p. 123.

27 The definition of trafficking in person is found in Article 3(a), 2000 United Nations Protocol to Prevent, Suppress and Punish Trafficking in Persons, Especially Women; and Children and reproduced in substance, but for the use of the term 'trafficking in human beings' within Article 4(a), 2005 Council of Europe Convention on Action against Trafficking in Human Beings. The following is the 2000 Palermo Protocol definition:

'Trafficking in persons' shall mean the recruitment, transportation, transfer, harbouring or receipt of persons, by means of the threat or use of force or other forms of coercion, of abduction, of fraud, of deception, of the abuse of power or of a position of vulnerability or of the giving or receiving of payments or benefits to achieve the consent of a person having control over another person, for the purpose of exploitation. Exploitation shall 
might be added, this genealogy has an even longer ascendancy as these specific terms appear as part of the concluding wishes of the London International Congress for the Suppression of the White Slave Traffic of 1899, noted above. The terms were themselves drawn for a comparative consideration of domestic legislation related to prostitution and the debauchery of minors - where the issue of abuse of authority was focused on teacher and tutors. ${ }^{28}$ As conceived during the 1902 negotiations, these elements of violence, threats, and abuse of authority were seen as means of compulsion, deemed "aggravating factors". ${ }^{29}$ When later the two offences noted above were reworked, the Drafting Commission stated as much, stating that "a fundamental distinction is drawn between girls under age and women, the act of procuring in itself being punishable in the case of girls under age, while in the case of women it has to be accompanied by certain aggravating circumstances". ${ }^{30}$

These two provisions setting out the offences, as finalised during the 1902 Conference, would ultimately find their way into the 1910 International Convention for the Suppression of the White Slave Traffic. However, two modification did take place during the 1902 Conference, the first, somewhat minor, was with regard to making plain that what was being legislated against was an international offence. ${ }^{31}$ Hence, the final clause in each of following provisions, as set out hire in italics:

\section{Article I}

Penalties shall be inflicted on any person who, to satisfy the passions of another, has procured, enticed, or led astray, even with her consent, a woman or girl under age with immoral intent, even where the various actions constituting the offence have taken place in different countries.

\section{Article II}

Penalties shall also be inflicted on any person who, to satisfy the passions of another has by fraud, violence, threats, abuse of authority, or any other means of compulsion procured, enticed, or led astray a woman or girl over age, with immoral intent, even where the various actions constituting the offence have taken place in different countries.

The second modification which transpired as between the Legislative Commission's proposal and the one that found its way into the 1910 International Convention for the Suppression of the White Slave Traffic, was fundamental: both in regard to the 1910 Convention, but also because of the contemporary echoes in regard to debates around the legalising of sex work.

This is so, as the proposal put forward by the Legislative Commission sought to establish "an essential distinction" between girls and women. That is: a distinction around the issue of age of consent as between those girls who are minors (fille mineur) and those over the age of majority (fille majeure). The dichotomy being made was as regards to girls under the age of

include, at a minimum, the exploitation of the prostitution of others or other forms of sexual exploitation, forced labour or services, slavery or practices similar to slavery, servitude or the removal of organs.

28 See relevant provision in Document Préliminaires, Ministère des Affaires Étrangères, Conférence Internationale pour la Répression de la Traite des Blanches, Documents Diplomatiques, 1902, at pp. 17-28.

29 Document Préliminaires and Rapport présenté par M. Ferdinand-Dreyfus, p. 123, Ministère des Affaires Étrangères, Conférence Internationale pour la Répression de la Traite des Blanches, Documents Diplomatiques, 1902 , pp. 23 and 123.

30 Commission de Rédaction, Rapport présenté par M. Louis Renault, Annexe au Procès-Verbal de la Septrième Séance, Ministère des Affaires Étrangères, Conférence Internationale pour la Répression de la Traite des Blanches, Documents Diplomatiques, 1902, p. 182; as translated in to English in: Correspondence respecting the International Conference on the 'White Slave Traffic', held in Paris, July 1902, House of Commons Parliamentary Papers (United Kingdom), Miscellaneous No. 3 (1905), Cd. 2667, p. 33.

31 See Procès-Verbaux des Séances, Quatrième Séance, Ministère des Affaires Étrangères, Conférence Internationale pour la Répression de la Traite des Blanches, Documents Diplomatiques, 1902, pp. 114-115. 
majority (re: minors), where consent was irrelevant; and for those who had reached the age of majority, wherein the crime was the leading astray, as a result the means of procurement: 'violence, threats, abuse of authority, compulsion or fraud'. Consider those provisions developed by the Legislative Commission once more:

1. Severely punished will be any person who, to satisfy the passions of another, shall have procured, enticed or led astray, even with her consent, an under-age girl, with immoral intent.

2. Equally will be punished any person who by violence, threats, abuse of authority, compulsion or fraud will have procured, enticed, or led astray a woman or a girl over age, with immoral intent. ${ }^{32}$

In detailing this distinction, the Report of the Legislative Commission went on to explain:

A minor does not have complete exercise over her free will. She is res sacra; the law must defend her, even against her own weakness. She who is in the majority can resist, at least in certain terms, it is only if her consent is by deceit, through force, or vitiated, that the law, less rigorous than morality, intervenes to supress the procurement. ${ }^{33}$

The Legislative Commission noted this distinction was to be found in domestic legislation in regard to proxenetism, that is: in regard to brokers who negotiated sex work; in the colloquial: pimping. The distinction also had the benefit, the Report noted: "of leaving aside the very serious question of the regulation of prostitution for which the Conference does not have a mandate thus making agreement easier to achieve". 34

However, the question of regulating prostitution did effectively rear its head during the consideration of these provisions during the Plenary Session, when the Italian Delegate, the Marquis Palucci de Calboli stated that he "regretted that Article 1 did not aim both at those of a majority as it did those of a minority". Effectively, he sought to establish an international offence of procurement of a woman with immoral intent; in other words: to criminalise the prostituting of others. While the Palucci de Calboli was willing to concede that a woman could deliver herself into prostitution, he believed there was "a necessity to make it a crime to procure even a girl over age". ${ }^{35}$ In response, the French Delegate, Mr. Ferdinand-Dreyfus noted:

That the legislation of the States represented at the Conference could be assembled into two distinct groups: the first, which punishes proxenetism without distinction between major or minor; the second, which distinguishes between these two categories of women. The criterion presented to the Legislative Commission was that the state of minority, of an under-age girl, was always a crime even where there was consent; but in regard to a girl over age, procurement is only punished if there is violence, fraud, threats, or coercion. To punish proxenetism, without taking note of this distinction, that is to raise the general and delicate question of prostitution. It would seem in wanting to resolve this, we risk not succeeding. Further, those delegates whose legislation is more rigorous have accepted the distinctions proposed, as constituting a minimum. To go further would be to compromise the successful efforts undertaking by the delegates. ${ }^{36}$

While it was agreed that the proposal by the Palucci de Calboli would be considered by the Drafting Commission, the issue was still discussed in Plenary Session, with word on the issue given to two others. The Delegate of the Netherlands, Mr. de Savornin Lorman, considered that the proposal introduced aggravating circumstances, in a situation where the Legislative Commission had been unwilling to consider such circumstances. He stated that the Legislative

\footnotetext{
32 Id., p. 123.

33 Id., p. 123. There are a number of possible translation of res sacra: sacred, sacred object, or sacred thing.

34 Id., p. 123. Re: "n'est pas saisie".

35 Procès-Verbaux des Séances, Quatrième Séance, Ministère des Affaires Étrangères, Conférence Internationale pour la Répression de la Traite des Blanches, Documents Diplomatiques, 1902, p. 113.

36 Id., p. 113.
} 
Commission "had agreed to leave this in the care of [domestic] legislatures"; "the Commission", de Savornin Lorman continued, "sought uniquely to establish a demarcation between minors and those of an age of majority". Renault, for his part, was in agreement stating that "the important question in regard to the international level is to establish two penalties. One for the procurement of minors, the other for the procurement of those who have attained the age of majority". ${ }^{37}$

When the Draft Convention was presented in the Report of the Drafting Commission, the proposal which had been put forward by Palucci de Calboli was found to have been included in Article 1 which read, in part, that "penalties shall be inflicted on any person who, to satisfy the passions of another, has procured, enticed, or led astray, even with her consent, a woman or girl under age with immoral intent". However, Renault, speaking as Rapporteur of the Drafting Commission was adamant that a distinction existed between Article 1, which was only applicable to minors, and Article 2, which was only applicable to those over the age of majority.

At first blush, Renault's words appear to go against a textual interpretation of the Article 1 which sets out that penalties are to be established for those who "to satisfy the passions of another, has procured, enticed, or led astray, even with her consent, a woman [...] with immoral intent". Yet, it would appear that the Italian Proposal had ultimately been dealt with by means of a classic example of legal nicety; wherein constructive ambiguity appears to provide one reading, while in law it meant another. In so doing, the one 'distinct group' of States, namely those who wished to address proxenetism writ large, failed to achieve their objective, though they went home thinking they had.

The compromise reached was the inclusion of term 'woman', but ultimately the reading of Article 1 turned on an interpretation of the word 'or'. This is so, as it will be recognised that in English (as with its French equivalent: 'ou'), the conjunction 'or' can in grammatical terms be used either as alternation or continuation. In the case at hand, the issue falls to the following wording: 'a woman or girl under age'. Should these words be understood as being in the alternative: 'a woman' or as 'a girl under age'; or as a continuation: as a 'woman or girl' under age. Again, at first blush, the former interpretation would seem to hold logically; an alternative can be understood between a woman and girl; or even a woman or a girl under age. Yet, through various means, the negotiations which transpired in 1902 and later in 1910, sought to maintain the distinction between Article 1 and Article 2 as being based on age by setting out markers which called for an contextual interpretation of these words as a grammatical continuation: as 'a woman or girl' under age. In other words: a person under age, whether called a girl or a women.

In this light, we can thus understand why Renault is adamant is emphasising that the distinction between Article 1 and 2 turns on age. As Renault explained in the Report of the Drafting Commission: "the requirement to suppress is defined in Articles I and II of the draft Convention; this establishes a fundamental distinction as between minors and those above the age of majority (entre les mineures et les majeures), the fact of procuring being punishable in the case of minors, while in case of those above the age of majority it must be accompanied by certain aggravating circumstances", ${ }^{38}$ Renault continues, seeking to emphasise that Article 1

37 Id., pp. 113-114.

38 Note here there is difference in the French text and its English translation which appears in the Parliamentary Papers. The provision quoted in the text above is a translation from the French and reads:

Le fait à réprimer est défini dans les articles 1 et 2 du projet de Convention; il comporte une distinction fondamentale entre les mineures and les majeures, le fait d'embauchage devant être puni par lui-même, taudis que, pour les majeures, il doit être accompagné de certaines circonstances aggravantes. 
only criminalised actions in regard to minors, but States, if they wish can go further and criminalise proxenetism in relation to those above the age of majority as well. The French jurist states that "there must be no misunderstanding as to the import of the definitions proposed by the Conference; they constitute the minimum that is considered indispensable". ${ }^{39} \mathrm{He}$ makes plain that the legislation in every country "must punish at least the acts which are indisputably abominable in the eyes of every one [...] because it is a question of persons who need to be protected on account of their age or of the machinations of which they are victims". Renault then provides a number of examples of where States can go further in their own legislation, the first being that States "may punish the procurement of those beyond the age of majority in the absence of the aggravating circumstances". ${ }^{40}$ Clearly, with the last statement, Renault is making plain that Article 1 does not apply to women over the age of majority, but rather, that if States wish to go beyond the purview of Article 1, it is their sovereign prerogative to put in place legislation which seek "to punish the procurement of those beyond the age of majority", where the aggravating circumstances of Article 2 are not at play.

Beyond this interpretive marker, other, more overt, markers were set out through the establishment of the Final Protocol - Protocol de Cloture - to the 1902 Draft Convention for the Suppression of the White Slave Traffic. The very raison d'être of the Final Protocol, despite its non-binding nature, was to provide interpretive guidance. The 1902 Draft Final Protocol says as much:

At the moment of proceeding to the signature of the Convention of this day, the undersigned Plenipotentiaries think it expedient to indicate the spirit in which Articles I, II, and III of that Convention should be interpreted, and in accordance with which it is desirable that, in the exercise of their legislative sovereignty, the Contracting States should provide for the execution of the arrangements decided upon or for completing them. ${ }^{41}$

Article A of the Draft Final Protocol speaks to Renault's reading of Articles 1 and 2; that these provisions constitute minimum threshold requirements for offences. Beyond this, the reading of Article A of the Final Protocol gives credence to a recognition that Article 1 of the

See Commission de Rédaction, Rapport présenté par M. Louis Renault, Annexe au Procès-Verbal de la Septrième Séance, Ministère des Affaires Étrangères, Conférence Internationale pour la Répression de la Traite des Blanches, Documents Diplomatiques, 1902, p. 182.

The Parliamentary Papers translate that provision as:

The act to be suppressed is defined in Articles I and II of the draft Convention; a fundamental distinction is drawn between girls under age and women, the act of procuring in itself being punishable in the case of girls under age, while in case of women it has been accompanied by certain aggravating circumstances.

Correspondence respecting the International Conference on the 'White Slave Traffic', held in Paris, July 1902 , House of Commons Parliamentary Papers (United Kingdom), Miscellaneous No. 3 (1905), Cd. 2667, p. 33.

39 Commission de Rédaction, Rapport présenté par M. Louis Renault, Annexe au Procès-Verbal de la Septrième Séance, Ministère des Affaires Étrangères, Conférence Internationale pour la Répression de la Traite des Blanches, Documents Diplomatiques, 1902, p. 182; as translated in to English in: Correspondence respecting the International Conference on the 'White Slave Traffic', held in Paris, July 1902, House of Commons Parliamentary Papers (United Kingdom), Miscellaneous No. 3 (1905), Cd. 2667, p. 34. Emphasis in the original.

40 Here again, the Parliamentary Papers use the term 'women' in the text rather than Renault's original words which were 'des majeures', that is: 'those above the age of majority'. I have thus translated from Commission de Rédaction, Rapport présenté par M. Louis Renault, Annexe au Procès-Verbal de la Septrième Séance, Ministère des Affaires Étrangères, Conférence Internationale pour la Répression de la Traite des Blanches, Documents Diplomatiques, 1902, p. 182; rather than the English translation found at: Correspondence respecting the International Conference on the 'White Slave Traffic', held in Paris, July 1902, House of Commons Parliamentary Papers (United Kingdom), Miscellaneous No. 3 (1905), Cd. 2667, p. 34.

41 Draft 'Protocole de Clôture' Correspondence respecting the International Conference on the 'White Slave Traffic', held in Paris, July 1902, House of Commons Parliamentary Papers (United Kingdom), Miscellaneous No. 3 (1905), Cd. 2667, p. 19. 
Draft Convention does not apply to women per se, but rather to women or girls who are underage, making plain that States can go beyond the requirements of Article 1 of the Draft Convention. That is, that States are free to punish those who - without the use of the means of compulsion - seek to satisfy the passions of others by procuring those beyond the age of majority with immoral intent. Article A of the Final Protocol of the 1902 Draft Convention for the Suppression of the White Slave Traffic reads:

The stipulations of Articles 1 and 2 are to be considered as a 'minimum' in the sense that it is understood that the Contracting Governments remain absolutely free to punish other similar offences, such, for instance, as the procuring of women over age, when their neither fraud nor compulsion. ${ }^{42}$

The issue would again arise during the negotiations which here held in 1910 which concluded the drafting of both the 1910 International Convention for the Suppression of the White Slave Traffic and its Final Protocol. Thus, the question will be returned to later in this Article when consideration turns to those 1910 negotiations. However, it might be emphasised here that what emerges from the negotiation of 1902 International Conference on the White Slave Traffic - and is later confirmed at the 1910 negotiations - is an interpretation of Articles 1 and 2 which speaks to a grammatical continuation which reads the following as phrases: 'a woman or girl under age' and 'a woman or girl over age'. Or for the sake of clarity: 1) a woman or girl who is under age and 2) a woman or girl who is over age.

In part, the difficulty in seeking to understand the nuances of language at play, at this point, hinges on the fact that the considerations remain abstract because no age of majority has been set. However, let us consider a counter-factual scenario whereby an age of majority had been set during the 1902 negotiations of say, for example, eighteen years of age. If State $X$, has designated sixteen years of age as being the age of majority within its domestic legislation; it might consider that 'girls' were those under the age of sixteen, whereas 'women' where those over sixteen years of age. Yet, from the perspective of the Draft Protocol, those women over sixteen years of age but under eighteen years would fall under the protection of Article 1 as 'a woman $[\ldots]$ under age'.

Here, it should be emphasised that while attempts were made during the 1902 negotiations to reach agreement as to a specific age of majority, this was unsuccessful. Instead, Article B of the Draft Final Protocol states: "For the suppression of offences contemplated in Articles I and II. The age of majority must be laid down in the civil law". ${ }^{43}$ When Article B was considered in Plenary Session, it was suggested that previous discussions had not turned on the benchmark of the civil law; rather it had been to call the attention of States to the utility of prolonging, in regard to the specific issue of the Conference, the period of age of minority as much as possible, so as to protect women for as long a possible, and thus render the suppression that much more energetic". ${ }^{44}$

The offences having been determined, consider now turns to the penalties, thought the Drafting Commission stated that the articles of the Draft Convention contain "no indication as to the penalties with which the offences are to be punished. That is the business of internal

\footnotetext{
42 There appears to be an issue with the English translation of this provision, as it appears in the League of Nations Treaty Series (Number 20, page 278), as the French term 'majeures' is translated as 'women over age' rather than the more accurate 'those above the age of majority'.

43 Draft Protocole de Cloture, Correspondence respecting the International Conference on the 'White Slave Traffic', held in Paris, July 1902, House of Commons Parliamentary Papers (United Kingdom), Miscellaneous No. 3 (1905), Cd. 2667, p. 19.

44 Procès-Verbaux des Séances, Septième Séance, Ministère des Affaires Étrangères, Conférence Internationale pour la Répression de la Traite des Blanches, Documents Diplomatiques, 1902, p. 170.
} 
legislation". ${ }^{45}$ This was, in fact, an acknowledgment of the internal/international dichotomy which was a fundamental theme which ran throughout the proceeding of the Conference and would ultimately require not one, but two international instruments. Having not been given Full Powers to conclude legal instruments, the Delegates were very much attuned to the nature of international relations, wherein State sovereignty reigned supreme; and said so, openly and often.

That said, Ferdinand-Dreyfus, who chaired the Legislative Commission, noted that in certain situations his Commission engaged in "its consideration with the traffic both internally and externally". He continued: "it would not be possible, or logical, or fair, to punish an external traffic if there is impunity as to the practice internally" ${ }^{46}$ For Mr. Buzzanti, the Italian Delegate, the Conference was meant to deal with both categories of the traffic: "it has been said that it is impossible to punish the offense internationally without punishing the domestic offense and that he did not logically suppose that any State could adhere to a future Convention without first having adopted measure to counter the traffic within the domestic order". ${ }^{47}$ Renault, for his part, would returned to this issue in the Report of the Drafting Commission, saying that as internal traffic was a domestic issue, "the offence takes on a purely territorial character"; however, it cannot "be disputed that it is inadmissible for a country to suppress external and not internal traffic". ${ }^{48}$ He continued: "both must be suppressed by legislation which is intended to be logical. Moreover, it may be said that the texts of Articles I and II take it for granted that internal traffic will be suppressed, if they do not lay stress upon it". ${ }^{4}$

In the Report prepared by the French Delegation on the Questions submitted for the Deliberations of the Conference in the lead-up to their meeting in Paris, it was clear that what was to transpire was a move to establish an international crime. To counter the nefarious acts, "the result of which was too often impunity", it was understood that the purpose of the Conference was "to oppose this internationalism by a group of international social forces which, exclusively, have the efficient means of putting it to an end". 50 Despite this internationalist perspective, concerns were raised as to the proposal by the Drafting Commission - in line with the one of the original questions that were put to the deliberations of the Conference - in regard to the holding of a girl in a house of debauchery which could "become, for her, a prison". ${ }^{1}$ The Russian Delegate, Mr. Malewsky-Maléwitch, considered this proposal to be an intervention into "the domain of domestic legislation of countries". For his part, Renault agreed, considering that this issue was situated within the territorial limits of

45 Commission de Rédaction, Rapport présenté par M. Louis Renault, Annexe au Procès-Verbal de la Septrième Séance, Ministère des Affaires Étrangères, Conférence Internationale pour la Répression de la Traite des Blanches, Documents Diplomatiques, 1902, p. 182; ; as translated in to English in: Correspondence respecting the International Conference on the 'White Slave Traffic', held in Paris, July 1902, House of Commons Parliamentary Papers (United Kingdom), Miscellaneous No. 3 (1905), Cd. 2667, p. 34.

46 Procès-Verbaux des Séances, Quatrième Séance, Ministère des Affaires Étrangères, Conférence Internationale pour la Répression de la Traite des Blanches, Documents Diplomatiques, 1902, p. 114.

47 Id., p. 115.

48 Id., p. 115.

49 Commission de Rédaction, Rapport présenté par M. Louis Renault, Annexe au Procès-Verbal de la Septrième Séance, Ministère des Affaires Étrangères, Conférence Internationale pour la Répression de la Traite des Blanches, Documents Diplomatiques, 1902, p. 183; as translated in to English in: Correspondence respecting the International Conference on the 'White Slave Traffic', held in Paris, July 1902, House of Commons Parliamentary Papers (United Kingdom), Miscellaneous No. 3 (1905), Cd. 2667, p. 34.

50 Rapport rédigé par la Délégation Française sur les Questions soumises aux délibérations de la Conférence, Document Préliminaires, Ministère des Affaires Étrangères, Conférence Internationale pour la Répression de la Traite des Blanches, Documents Diplomatiques, 1902, p. 16.

51 Commission Législative, Rapport présenté par M. Ferdinand-Dreyfus, Annexe au Procès-Verbal de la Quatrième Séance, Ministère des Affaires Étrangères, Conférence Internationale pour la Répression de la Traite des Blanches, Documents Diplomatiques, 1902, p. 123. 
each State and thus fell "exclusively within the domain of territorial sovereignty"; as such, it was within the jurisdiction of the police and was not to be dealt with "by virtue of an international engagement". ${ }^{52}$ As a result of these discussions, the proposed offense related to sequestration within houses of ill-repute was shelved.

The issue of the distinction between international and domestic jurisdictions did not only animate the discussions with regard to offences; in fact it did much more, shaping both the outcome of 1902 International Conference on the White Slave Traffic and the very regime of white slave traffic. Renault recognised this fundamental issue:

The problem of the suppression of this criminal traffic raises both national and international questions. The Governments may consent to come to an understanding and give undertakings in regard to international questions as long as their sovereignty is respected, but they cannot, by an international act, undertake to realize any particular reform of an exclusively national character, because this would involve an encroachment on the domain proper of their internal sovereignty.

Renault then ended the introduction to the Report of the Drafting Commission, in the following manner:

In respect of the international questions, we could propose to the Governments to come to an agreement, to give undertakings, at least to a certain extent; in respect of the national questions we had to restrict ourselves to the expression of wishes and to more or less urgent recommendations. The difficulty arises from the fact that the distinction is not always very clearly defined, and that the questions often present themselves under a double aspect. It is then necessary to proceed with great caution, and to take into consideration both the international engagement and the domestic measure.

It is in this general spirit that we have endeavoured to adapt the Resolutions of the Conference to a wording which could be submitted to our Governments without arousing the susceptibilities of any of them. [...]

You will find at the end of this Report the draft Final Protocol, [...] This Protocol, contains the result of our deliberations, which we propose to record under several heads adapted to the nature of the questions dealt with; we request you to submit to our Governments: 1. a Draft International Convention with a draft Protocol de Clôture annexed; 2. a Draft Agreement. ${ }^{53}$

\section{International Agreement for the Suppression of the White Slave Traffic}

During its early deliberations the Belgian Delegate, Mr. Hoyois, had pointed the way to the solution ultimately accepted by the 1902 International Conference on the White Slave Traffic: that two binding instruments would be drafted. Hoyois noted that a distinction could first be made between non-binding proposals (those recommendations constituting the Draft Final Protocol) made to States; and others, binding, proposals. Those binding proposals could then be separated into "two categories: those that have as object legislative measures and those which are administrative measure. Both could, and no doubt should, find their way into international agreements". He then set out his rationale:

On certain points, in effect, the approval of Governments could be more easily gaining than in others. This would be the case for most of the resolution of the Conference related to measures of an administrative kind. On the administrative plane, Governments are in position, if need be, to make modifications to the actual state

\footnotetext{
52 Procès-Verbaux des Séances, Quatrième Séance, Ministère des Affaires Étrangères, Conférence Internationale pour la Répression de la Traite des Blanches, Documents Diplomatiques, 1902, pp. 114-115.

53 Commission de Rédaction, Rapport présenté par M. Louis Renault, Annexe au Procès-Verbal de la Septrième Séance, Ministère des Affaires Étrangères, Conférence Internationale pour la Répression de la Traite des Blanches, Documents Diplomatiques, 1902, p. 180; as translated in to English in: Correspondence respecting the International Conference on the 'White Slave Traffic', held in Paris, July 1902, House of Commons Parliamentary Papers (United Kingdom), Miscellaneous No. 3 (1905), Cd. 2667, p. 33.
} 
of things much quicker than in the domains where they can only act after the eventual intervention of their respective parliaments. ${ }^{54}$

It was for these reasons that ultimately the 1902 International Conference spawned two instruments; and saw the Draft Agreement come into force shortly thereafter, while the Draft International Convention not only took longer to gain consent, but required a further international conference to do so.

It will be recalled that amongst the questions that were to form the object of deliberation of the 1902 Conference, the French Government had proposed, as the final elements of an international convention to be concluded, the following:

4. The supervision of the departure and arrival of persons suspected of the denounced practices, and of their victims; the transmission of information to the Governments concerned respecting the domicile of the latter, and their repatriation;

5. The instructions to be given to the Diplomatic or Consular Agents of the various foreign Governments. ${ }^{55}$

In the Report prepared by the French Government regarding these questions to be considered during the Conference, it noted that:

if the discovery of the procurement of women and girls, in the great urban metropolitans where it is ordinarily practiced presents, for a hundred different reasons, extreme difficulties, it is not the same on the platforms of arrival and departure, on the trains which carry these unfortunate travellers, in the ports of embracement or on the ships which will transport them beyond the seas. Here, there are abundant controls and these can be exercised with success by agents who, with experience, have become very shrewd. ${ }^{56}$

In the Report of the Administrative Commission prepared during the 1902 Conference, it was noted that the Commission had been encouraged to develop administrative measures which could be voluntarily accepted by States. The Commission was in agreement that there was "the need to establish the methodical international surveillance of the circulation" of those who might be caught up in the white slave traffic; but that, in the words of the Rapporteur of the Administrative Commission, the French Delegate, Mr. Hennequin, this should not "limit freedom of movement". ${ }^{57}$ Beyond this, there was very little engagement or thoughts expressed as to the nature of the administrative measures that were being considered: that is, those proposed measures put forward by the French Government in the lead up to the 1902 Conference. The light touch given by the Administrative Commission was also reflected in the considerations of the Report of the Administration Commission by the Plenary Session, despite the fact that its proposal were more voluminous that the reports of other commissions. Throughout these discussions, one gets the sense that the Delegates considered these

54 Procès-Verbaux des Séances, Troisième Séance, Ministère des Affaires Étrangères, Conférence Internationale pour la Répression de la Traite des Blanches, Documents Diplomatiques, 1902, p. 107.

55 See fn. 11. "Questions Submitted to the Consideration of the Conference", Correspondence respecting the International Conference on the 'White Slave Traffic', held in Paris, July 1902, House of Commons Parliamentary Papers (United Kingdom), Miscellaneous No. 3 (1905), Cd. 2667, p. 6.

Note also a Report prepared by the French Delegation with regard to the Questions Submitted to the Consideration of the Conference; and the Response by the German Government appended hereto: Document Préliminaires, Ministère des Affaires Étrangères, Conférence Internationale pour la Répression de la Traite des Blanches, Documents Diplomatiques, 1902, pp. 16-45; which considered the legislation, administrative measures, and measure related to jurisdiction and procedure, in relation to the State participating in the Conference.

56 Mesures Administrative, Document Préliminaires, Ministère des Affaires Étrangères, Conférence Internationale pour la Répression de la Traite des Blanches, Documents Diplomatiques, 1902, p. 38.

57 Commission Administative, Rapport présenté par M. Hennequin, Annexe au Procès-Verbal de la Cingième Séance, Ministère des Affaires Étrangères, Conférence Internationale pour la Répression de la Traite des Blanches, Documents Diplomatiques, 1902, p. 138. 
administrative arrangements to be of a second order and that they would, in all likelihood, be deemed non-binding recommendations rather than what, in fact, transpired: their transformation, shortly thereafter, into a binding instrument. In part, this was due to the fact that the Report of the Administrative Commission set out its ultimate findings not in the form a draft legal instrument, but rather as a number of resolutions. As to the substance of its ultimate consideration, the first of the Resolutions put forward by the Commission was general in nature, reading:

Constant and active watch to be kept in all the railway stations, and particularly on the frontiers and in the ports, with a view to the detection, as far as is possible and is allowed by law, of the persons in charge of girls and women who are destined for immoral purposes, and who are in ignorance of the fact, or even, in the case of girls under age, those who are acquainted with the intent.

The Commissioner of Emigration at ports of embarkation to be allowed, if necessary, to examine individuals suspected of being engaged in the White Slave Traffic, such examination to bear, in the case of women, on the places of departure and destination, their civil status, and the profession they contemplate pursuing abroad. ${ }^{58}$

Where the work of the Administrative Commission was transformed into the Draft Agreement which would later become the 1904 International Agreement for the Suppression of the White Slave Traffic, was through the work of the Drafting Commission of the 1902 Conference. As concluded, the Draft Agreement required each consenting State to establish an authority to act as a central clearing-house of information regarding "the procuring of women or girls for immoral purposes abroad"; to kept watch in line with the Resolution noted above; to interrogate foreign prostitutes; to assist in the repatriation of both victims and foreign prostitutes wishing to return to their country of origin; and, finally, to supervise "office and agencies engaged in finding employment for women or girls abroad". 59

When considering the text in the Report of the Drafting Commission, Renault was prophetic in noting that the provisions of the Draft Agreement "are of quite a different character from those of the Convention; further, what is more important from a practical point of view, the putting into force of this Agreement seems capable of more rapid achievement than that of the Convention". This was so, as:

For the latter Parliamentary approval will in many cases be required, and special Laws will have to be voted, all of which necessarily, and with the best of will, entails considerable delay. The Arrangement seems capable of acceptance by the different Governments in virtue of their ordinary powers; they are only asked to agree on the employment of existing instruments, not to create new ones. It would certainly be a great step forward if our different countries could agree within a short time on administrative measures for paralyzing the traffic, detecting its commencement, and protecting the unfortunate women who are its victims. ${ }^{60}$

With the closing of the International Conference on the White Slave Traffic on 25 July 1902, States were left to consider whether they would move forward to bring both the Draft

${ }^{58}$ Commission Administative, Rapport présenté par M. Hennequin, Annexe au Procès-Verbal de la Cingième Séance, Ministère des Affaires Étrangères, Conférence Internationale pour la Répression de la Traite des Blanches, Documents Diplomatiques, 1902, p. 142; as translated in to English in: Correspondence respecting the International Conference on the 'White Slave Traffic', held in Paris, July 1902, House of Commons Parliamentary Papers (United Kingdom), Miscellaneous No. 3 (1905), Cd. 2667, p. 13.

59 International Agreement for the Suppression of the White Slave Traffic, League of Nations, Treaty Series, Volume 1(1), 1920, pp. 85-87. See Appendix I for the provision of the 1904 International Agreement for the Suppression of the White Slave Traffic.

60 Commission de Rédaction, Rapport présenté par M. Louis Renault, Annexe au Procès-Verbal de la Septième Séance, Ministère des Affaires Étrangères, Conférence Internationale pour la Répression de la Traite des Blanches, Documents Diplomatiques, 1902, p. 18; as translated in to English in: Correspondence respecting the International Conference on the 'White Slave Traffic', held in Paris, July 1902, House of Commons Parliamentary Papers (United Kingdom), Miscellaneous No. 3 (1905), Cd. 2667, p. 37. 
Arrangement and Draft Convention into force. In April 1903, the French Government suggested that the time was ripe to do just that; circulating a Note asking if States were in a position to carry out these formalities. In February 1904, the Negotiating Parties were contacted once more by France to say that while States were prepared to proceed to consent to the Arrangement; that with regard to the Convention, "in view of the fact that several Governments are unable to assure its execution without previously altering their legislation, that the signature should be postponed". 61

On 18 May 1904, the International Agreement for the Suppression of the White Slave Traffic was signed. During those ceremonies, at the behest of the Dutch Government which had noted, in February 1904, that it was unclear if the Agreement would be applicable within the respective colonies, the French Government added a Declaration to that effect for the consideration of the Signatory Parties. ${ }^{62}$ The International Agreement for the Suppression of the White Slave Traffic came into force on 18 July 1905 with ultimately twelve States ratifying; nine more acceding; and a further large number becoming party as a result of their adherence to the 1910 International Convention for the Suppression of the White Slave Traffic. By way of closing the bracket on the 1904 International Agreement for the Suppression of the White Slave Traffic, it should be noted that it has been superseded by the 1950 Convention for the Suppression of the Traffic in Persons and of the Exploitation of the Prostitution of Others, which consolidates the 1904 Agreement and other instruments, thus leading to the - rather remote - possibility of termination of the 1904 International Agreement for the Suppression of the White Slave, were all its Parties to bind themselves to the 1950 Convention. ${ }^{63}$

\section{International Convention for the Suppression of the White Slave Traffic}

In January 1910, the German Ambassador in Paris wrote to the French Foreign Minister, stating that his Government's proposal to hold a conference on the suppression of obscene publications had been inspired by the decisions made during the 1902 Conference related to the white slave traffic. In the context of a general willingness of European States to address vice, Germany's Imperial Government wanted the agreements on obscene publications to mirror as much as possible those that had been agreed to in 1902 in regard to the white slave traffic. The German

61 Declassé to Sir E. Monson, Enclosure Number 14, Correspondence respecting the International Conference on the 'White Slave Traffic', held in Paris, July 1902, House of Commons Parliamentary Papers (United Kingdom), Miscellaneous No. 3 (1905), Cd. 2667, p. 44.

62 See Procès-verbal of Signature, Enclosure 2 in No. 19, Correspondence respecting the International Conference on the 'White Slave Traffic', held in Paris, July 1902, House of Commons Parliamentary Papers (United Kingdom), Miscellaneous No. 3 (1905), Cd. 2667, p. 52.

THE undersigned Plenipotentiaries, assembled this day for the purpose of proceeding to the signature of the Arrangement intended to secure effective protection against the 'White Slave Traffic' have exchanged the following Declaration as regards the application of the said Arrangement to the respective Colonies of the Contracting States:-

Article 1. The countries, signatories of the Arrangement mentioned above, shall have the right to accede thereto at any time for their Colonies or foreign possessions. They may do this either by a general Declaration comprehending all their Colonies or possessions within the accession, or by specially naming those comprised therein, or by simply indicating those which are excluded.

Article. 2. Each Government shall make the Declaration which it shall think suitable.

Article. 3. The Governments who shall have subsequently to make Declarations with regard to their Colonies, shall do so in the form laid down by Article 7 of the Arrangement.

63 Information in this paragraph available via the United Nations Treaty Collection, Multilateral Treaties Deposited with the Secretary-General, Chapter VII, Number 8, available at: https://treaties.un.org/. 
Ambassador went on to say that, as the Conference relating to obscene publication, which was to transpire shortly in Paris, would include "all those States interested in the suppression of the White Slave Traffic, it seemed an opportune time to profit from the occasion to once more take up the discussions of the [1902 Draft] Convention. ${ }^{64}$ Having sounded out his counterparts; in February, the French Foreign Minister noted that those who had negotiated the Draft Convention seemed willing to "make some minor changes [re: retouches] necessary to allow this diplomatic instrument to be signed without delay". However, the French Minister, Stephen Pichon, was clear in seeking to bracket the negotiations, stating that: "it should be clearly understood that the discussions on the subject, will only touch on the reservations which different States have in regard to the text drafted in 1902." 65

It is worth pausing here for a moment to consider the regime of reservation to treaties which existed in international law at the time, as it was this technical, legal, issue which both blocked the coming into force of the 1902 Draft Convention and precipitated the need to hold a second round of negotiations so as to iron out the difficulties. In essence, the nature of public international law at the time: little more than a jus publicum Europeaum; established that a reservation to a treaty would only be acceptable if all other parties to that treaty accepted it. While this regime of treaty reservations would give way during the United Nations era; in the wake of the 1902 International Conference on the White Slave Traffic it effectively blocked the coming into existence of the Draft Convention. ${ }^{66}$ The fact that, having had their domestic legal orders consider the 1902 Draft Convention, resulted in a number of States having difficulties in being able to consent to becoming party to it without various reservations, meant that the Draft Convention was effectively dead in the water. The only means of seeking to bring it back to life was to have the parties sit down at the same table and talk through those reservation which they had with the text.

In 1910, they did just that, literally: sitting at the same table, in the same room, as they had in 1902, at the First International Conference for the Suppression of the White Slave Traffic. Not only that, but a number of Delegates who were present in 1902, including Hennquin and Renault found themselves, on 18 April 1910, once again in Paris at the salons du Ministères des Affairs étrangères, accredited to take up the negotiations during what was now the Second International Conference for the Suppression of the White Slave Traffic. The Delegates were in fact representing their Governments at the both this Conference and the concurring International Conference on the Suppression of Obscene Publications. This is manifestly

64 Ministère des Affaires Étrangères, Deuxiéme Conférence Internationale pour la Répression de la Traite des Blanches, Documents Diplomatiques, 1910, p. 11.

65 Id., p. 13.

66 In essence, a reservation is a unilateral act which would allow a State to opt-out or exclude itself from an article of a treaty. Article 2(d) of the 1969 Vienna Convention on the Law of Treaties defines a reservation as:

a unilateral statement, however phrased or named, made by a State, when signing, ratifying, accepting, approving or acceding to a treaty, whereby it purports to exclude or to modify the legal effect of certain provisions of the treaty in their application to that State.

The change from what was previously understood as the bilateral nature of reservations (wherein each State had to, bilaterally, agree to the reserving State's proposed modification, before that State can be deemed a party to the treaty in question); to the current multilateral nature of reservations (wherein, the reserving State becomes party to a treaty when at least one States agrees to its reservations), came about as a result of both the Advisory Opinion of the International Court of Justice in the 1951 Reservations to the Convention on the Prevention and Punishment of the Crime of Genocide case; and the provisions later included in the 1969 Vienna Convention on the Law of Treaties (see Articles 19-23).

While the current multilateral system of reservations is rather more technical then has just been set out, it goes beyond the purview of this study to provide more detail. For those interested, see generally: Jean Kyongun Koh, "Reservations to Multilateral Treaties: How International Legal Doctrine Reflects World Vision", (1982) 23 Harvard International Law Journal 71-116. 
evident by the Opening Session which was devoted to the inaugurating both Conferences, jointly, before the first turning its attention to the 1902 Draft Convention. The basis of discussion during the deliberations of the Second International Conference for the Suppression of the White Slave Traffic were both: the reservations made by Germany, The Netherlands, and Sweden; and the Notes, by Belgium and by France, giving these reservations consideration.

In his opening address to the Second International Conference, Pichon made plain that his Government sought to have the 1902 Draft Conventions come into force. The eight year delay which had transpired was a recognition that this task had been difficult, "as, to be made good, it was necessary for the different States to introduce into their respective legislation an offence which, previously had not existed". While this task was effectively complete, yet there "were objections to minor details or drafting language which had made it impossible for the 1902 accord to be officially recognised". ${ }^{67}$ Thus, to speed up the process, which could otherwise have occurred through diplomatic correspondence, the French Government thought it best to have this Second Conference transpire in parallel to the Conference related to obscene publications.

There were two issues which animated the discussions at the 1910 Second International Conference for the Suppression of the White Slave Traffic, the first was the procedural elements of effecting cooperation on criminal matters as between States. This, in fact, was the third sets of issues considered at the 1902 negotiations, after matters of administration and legislation: issues of jurisdiction and procedures. ${ }^{68}$ While issues of jurisdiction were straight forward, the issues of procedure, and specifically the channels by which cooperation between States would transpire raised concerns that needed to be revisited in 1910. The issue of 'Letter of Requests' (re: commissions rogatoires) was rather technical in nature and demonstrated different approaches as to how communication should transpire State to State. The ultimate solution, which was negotiated at the Second International Conference for the Suppression of the White Slave Traffic in 1910 was to provide a plurality of options, which thus took into consideration various approaches States had developed, whether that be communication directly judge to judge, through the intermediaries of consular agents, or through diplomatic channels. ${ }^{69}$

The second item of note which engaged the 1910 negotiations in Paris was the issue age of minority/majority and where to draw the line. Before considering those discussions, it will be recalled that the offences envisioned within the 1902 Draft Convention were ultimately incorporated into the 1910 International Convention for the Suppression of the White Slave Traffic. In the evolution of our considerations thus far, no official translation into English of the provisions of Articles 1 and 2 of the 1910 International Convention for the Suppression of the White Slave Traffic has been set out. The following is drawn from the United Kingdom Treaty Series:

\footnotetext{
67 Procès-Verbaux des Séances, Premième Séance, Ministère des Affaires Étrangères, Deuxiéme Conférence Internationale pour la Répression de la Traite des Blanches, Documents Diplomatiques, 1910, p. 43.

68 Issues of jurisdiction in regard to these international crimes was of minor deliberation, it having been noted that the Institut de droit international had, in its session of 1883 in Munich set out a number of principles which clarified the issue. See Document Préliminaires, Ministère des Affaires Étrangères, Conférence Internationale pour la Répression de la Traite des Blanches, Documents Diplomatiques, 1902, p. 34. Also consider: Institut de droit international, "Règles relatives aux conflits des lois pénales en matière de competence", Munich Session, 1883 available at: http://www.justitiaetpace.org/idiF/resolutionsF/1883 mun_04_fr.pdf.

69 Those discussions can be found in Ministère des Affaires Étrangères, Conférence Internationale pour la Répression de la Traite des Blanches, Documents Diplomatiques, 1902, at pp. 34-37, 159-161, 185-187; and Ministère des Affaires Étrangères, Deuxiéme Conférence Internationale pour la Répression de la Traite des Blanches, Documents Diplomatiques, 1910, pp. 49-54, 87-89; and manifest in Article 6, of the 1910 International Convention for the Suppression of the White Slave Traffic found in Appendix II.
} 
Article 1

Whoever, in order to gratify the passions of another person, has procured, enticed, or led away, even with her consent, a woman or girl under age, with immoral purposes, shall be punished notwithstanding that the various acts constituting the offence may have been committed in different countries.

\section{Article 2}

Whoever, in order to gratify the passions of another person, has, by fraud, or by means of violence, threats, abuse of authority, or any other means of compulsion, procured, enticed, or led astray a woman or girl over age, for immoral purposes, shall also be punished, notwithstanding that the various acts constituting the offence may have been committed in different countries. ${ }^{70}$

During both the deliberations of the Drafting Commission and during the Plenary Session of the 1910 Second International Conference for the Suppression of the White Slave Traffic, an attempt was made by the Hungarian Delegation to have the provisions of Article 1 and 2 reopened for discussion. However, this was not to be, "as no formal proposal for modifying Articles 1 and 2 of the draft Convention of 1902 had been circulated to the different Powers, the Conference could not consider a suggestion of the Hungarian Government that an age limit of 20 should be substituted for references in those Articles to 'majority' and 'minority". ${ }^{71}$

Instead, the Hungarian Proposal was handed to a Sub-Commission of the Commission relative to the Repression of the White Slave Traffic head by none other than Louis Renault. The Sub-Committee, it was reported, noted that the 1902 Draft Convention provided more protection to a woman or girl under age procured for foreign debauchery than to a woman or girl over age, but without however entering into any specificities as to the terms 'under age and over age"". ${ }^{72}$ The Report of the Commission noted that to leave the provisions of Article B as they now stood - it will be recalled these stated: "For the suppression of offences contemplated in Articles I and II. The age of majority must be laid down in the civil law" - would leave a gap between the different ages of majority established in the civil law of various States. This could lead to a situation where States punished the same offence differently, "or even not punishing a trafficker at all, where he had procured a foreign women or girl from a country where the age of civil majority was different. The repression could thus be severally compromised". Although recognising that to set such an age would be "rather arbitrary", it was considered to it was a better option than to refer to domestic civil law generally. ${ }^{73}$

For its part, the Sub-Commission considered that 'the terms person 'under age' and 'over age' (re: majeures and mineures) did not have any absolute meaning and that many different interpretations could be given to them. These terms have, in reality, but a relative meaning and, by reference to their etymology, it came to be realised that they simply meant 'more old' or "less old"". 74 Having considered the rather young age ("11, 13, or 16 years of age") for making the distinction between age of minority and majority in regard to different legislation

70 International Convention for the Suppression of the White Slave Traffic, 1910, United Kingdom Treaty Series, 1912, Number 20, pp. 269-270, House of Commons Parliamentary Papers (United Kingdom), Cd. 6326. Available from UK Treaties Online, at: http://treaties.fco.gov.uk/docs/pdf/1912/TS0020.pdf.

71 Report of the British Delegation to Sir Edward Grey, International Conference of the Drat Convention of 1902, respecting the White Slave Traffic, No. 6, Correspondence respecting the International Conference on Obscene Publications and the 'White Slave Traffic', held in Paris, April and May 1910, House of Commons Parliamentary Papers (United Kingdom), Cd. 6547, p. 27.

72 Commission de Rédaction, Rapport présenté par M. Charles Alphand, Annexe Numéro 1, Annexes au ProcèsVerbal de la Deuxième Séance, Ministère des Affaires Étrangères, Deuxième Conférence Internationale pour la Répression de la Traite des Blanches, Documents Diplomatiques, 1910, p. 66.

73 Commission de Rédaction, Rapport présenté par M. Charles Alphand, Annexe Numéro 1, Annexes au Procès-Verbal de la Deuxième Séance, Ministère des Affaires Étrangères, Deuxième Conférence Internationale pour la Répression de la Traite des Blanches, Documents Diplomatiques, 1910, pp. 66 and 67.

$74 \quad$ Commission de Rédaction, Rapport présenté par M. Charles Alphand, Annexe Numéro 1, Annexes au Procès-Verbal de la Deuxième Séance, Ministère des Affaires Étrangères, Deuxième Conférence Internationale pour la Répression de la Traite des Blanches, Documents Diplomatiques, 1910, p. 67. 
on the crime of rape; the Commission considered that they should set an age, but that this be recognised as a minimum, while it would be up to States to protect minors up to that age, but were welcome to go further, even go as far as not to use age as a condition in regard to violation so Article 1.

Having set out its considerations, the Commission moved "to fix a uniform minimum age under which the repression should be established for the offence of White Slave Traffic, even without fraud or violence, and to that end decided by a majority to fix that age at 21 completed years". ${ }^{75}$ As a result of a threat of a Swiss reservation to this provision, the age was lowered to 20, so that the new Article B of the Final Protocol of what would become the 1910 International Convention for the Suppression of the White Slave Traffic reads:

As regards the suppression of the offences provided for in Articles 1 and 2, it is fully understood that the words 'woman or girl under age, woman or girl over age' refer to women or girls under or over twenty completed years of age. A law may, nevertheless, fix a more advanced age for protection, on condition that it is the same for women or girls of every nationality. ${ }^{76}$

It will be recalled that it was an open question whether the wording of Article 1 created an offence of proxenetism, that is: of prostituting another person in generally; or whether it created an offence specifically in regard to under aged girls. The issue turnes on the phrase 'women or girl under age'. Should this phrase be read, in light of the conjunction 'or', in grammatical terms as alternation or continuation? The answer appears clear: it should be read as continuation, as a phrase "a woman or girl under age" or, for the sake of clarification: as meaning 'a woman under age' and 'a girl under age'.

Not only do we have the weight of the considerations which were given during the negotiation of the 1902 International Conference on the White Slave Traffic, but the wording of Article B of the Final Protocol attached to the 1910 International Convention on the White Slave Traffic sets out this reading of grammatical continuation when it refers to "women or girls under or over twenty". To add weight to this reading, there is no attempt in Article B to provide a alternation when considering women as opposed to, for instance 'girls under age'; rather, the wording is set out as phrases, in quotation marks: 'woman or girl under age, woman or girl over age'. Finally, if one refers back to the Article 1 of the 1910 International Convention on the White Slave Traffic the words 'a woman or girl under age' are separated by commas from what comes before and what comes after, and thus an independent clause which further adds weight to it being read as a phrase; grammatically as continuation.

It will be recognised, and was recognised as such by the negotiators at the 1902 International Conference on the White Slave Traffic, that the Final Protocol is non-binding. Thus, the question should be broached as to what weight can be afforded to the provisions of the Final Protocol to the 1910 International Convention on the White Slave Traffic as an interpretative guide or marker, in light of its non-binding character? The answer to that question is to be found in the rules of treaty interpretation.

First, it should be understood that the considerations given to the issue at hand during the 1902 and the 1910 International Conferences may assist in interpreting the provisions of the phrase 'a woman or girl under age', but only in supplementary fashion. This is so, as the negotiations are part of the preparatory work of the treaty, and as such the 1969 Vienna

75 Commission de Rédaction, Rapport présenté par M. Charles Alphand, Annexe Numéro 1, Annexes au Procès-Verbal de la Deuxième Séance, Ministère des Affaires Étrangères, Deuxième Conférence Internationale pour la Répression de la Traite des Blanches, Documents Diplomatiques, 1910, pp. 67 and 68. Emphasis in the original.

$76 \quad$ International Convention for the Suppression of the White Slave Traffic, 1910, United Kingdom Treaty Series, 1912, Number 20, p. 278, House of Commons Parliamentary Papers (United Kingdom), Cd. 6326. Available from UK Treaties Online, at: http://treaties.fco.gov.uk/docs/pdf/1912/TS0020.pdf. 
Convention on the Law of Treaties makes plain that this travaux préparatoires can assist in confirming a meaning of such a phrase, where there is ambiguity resulting from the an interpretation in concert with the general rule of treaty interpretation set out in Article 31(1) of the 1969 Vienna Convention on the Law of Treaties. ${ }^{77}$ That provision of Article 31(1) sets out the general rule of treaty interpretation in the following terms: "A treaty shall be interpreted in good faith in accordance with the ordinary meaning to be given to the terms of the treaty in their context and in the light of its object and purpose". The Vienna Convention then goes on to spell out what is meant, in part, by the 'context'. Article 31(2) states that: "the context for the purpose of the interpretation of a treaty shall comprise, in addition to the text, including its preamble and annexes: (a) any agreement relating to the treaty which was made between all the parties in connexion with the conclusion of the treaty".

In the Commentary to these provisions provided by the United Nations International Law Commission, it stated that the provisions of Article 31(2) seek "to define what is comprised in the 'context' for the purposes of the interpretation of the treaty. That the preamble forms part of a treaty for purposes of interpretation is too well settled to require comment, as is also the case with documents which are specifically made annexes to the treaty". ${ }^{78}$ Here then we see that despite the Final Protocol being deemed non-binding, it is recognised in law that it should be taken into account when interpreting the provisions of the 1910 International Convention on the White Slave Traffic. In its Commentary on the provisions related to treaty interpretation, the International Law Commission noted that items such as the Final Protocol, which are agreements related to a treaty made by all the Parties "in connection with the conclusion of the treaty" should be understood as more than simply preparatory works, rather they add substance to the 'context' element, for the purposes of treaty interpretation. In the words of the Commission:

What is proposed in paragraph 2 is that, for purposes of interpreting the treaty, these categories of documents should not be treated as mere evidence to which recourse may be had for the purpose of resolving an ambiguity or obscurity, but as part of the context for the purpose of arriving at the ordinary meaning of the terms of the treaty. ${ }^{79}$

The in-depth consideration given to the phrase 'a woman or girl under age' and the grammatical use of the conjunction 'or', leads to the conclusion that the provision of Article 1 of the 1910 International Convention on the White Slave Traffic are to be interpreted to mean that its provisions are only applicable to females who are under age, be they women or girls. What that age is was ultimately left to the domestic jurisdiction of each State to decide. Thus, the 1910 Convention does not criminalise the prostitution of others. At Article 2, it criminalises the exploitation of prostitutes where the various means of compulsion are at play. At Article 1, it establishes that consent is vitiated for those who are under age. For those above the age of majority - for those who are deemed to be able to consent - the 1910 International Convention on the White Slave Traffic is silent.

The Second International Conference for the Suppression of the White Slave Traffic having been brought to a close on 2 May 1910, the International Convention for the Suppression of

77 See Article 32, Vienna Convention on the Law of Treaties, 1969.

78 United Nations, International Law Commission, Yearbook of the International Law Commission, Volume II, 1966, UN Doc. A/CN.4/SER.A/1966/Add.1, p. 221.

Note that customary nature of provisions such as those of Article 31 of the Vienna Convention on the Law of Treaties are "practically undisputed". See Karl Zemanek, Introductory Note: Vienna Convention on the Law of Treaties, 2009, p.1. Available at: http://legal.un.org/avl/pdf/ha/vclt/vclt-e.pdf.

79 United Nations, International Law Commission, Yearbook of the International Law Commission, Volume II, 1966, UN Doc. A/CN.4/SER.A/1966/Add.1, p. 221. 
the White Slave Traffic was signed two days later and came into force on 8 August $1912 .{ }^{80}$ Like the 1904 International Agreement for the Suppression of the White Slave Traffic, a Declaration regarding colonial possession was also open for signature at the time of ratification. The 1910 International Convention for the Suppression of the White Slave Traffic ultimately had thirteen States ratify its provisions; a further twenty-two acceded, with six other States manifesting consent through succession. As was noted previously, the 1910 International Convention for the Suppression of the White Slave Traffic, like the 1904 International Agreement for the Suppression of the White Slave Traffic, is superseded by the 1950 Convention for the Suppression of the Traffic in Persons and of the Exploitation of the Prostitution of Others. While there remains a theoretical possibility that the 1910 International Convention will be terminated, this is rather remote as the 1950 Convention has itself been overtaken by the 2000 Palermo Protocol to Prevent, Suppress and Punish Trafficking in Persons, Especially Women and Children. As a result, there is very little likelihood that States that are Party to the 1910 International Convention will expend legislative energy to consent to the 1950 Convention, leading to the demise of the 1910 International Convention for the Suppression of the White Slave Traffic, or for that matter, the 1904 International Agreement for the Suppression of the White Slave Traffic. ${ }^{81}$

\section{Conclusion}

This study has considered the first of the three eras of evolution, at the international level, of the regime of what is today known as human trafficking. The development, in the pre-League of Nations era, of the white slave traffic regime during the first decade of the $20^{\text {th }}$ Century bears witness to jilted move from bilateralism to multilateralism in European diplomacy. In this instance, the experiment of the 1902 International Conference on the White Slave Traffic failed, as its primary consideration - to produce a draft convention which could be brought into force - was unsuccessful. States were required to then reload, holding a Second International Conference on the White Slave Traffic in 1910 to give effect to the work undertaken eight years previously. The result was the conclusion of the International Convention for the Suppression of the White Slave Traffic.

The negotiations of that instrument has highlighted a bit of a lost history which is of relevance to contemporary considerations of human trafficking: that it was self-evident then that States should punish trafficking both internationally and domestically. The negotiations demonstrate that despite the two camps - those States that advocated for the international criminalisation of the prostitution of others, and those that advocated the suppression of the exploitation of the prostitution of others - the outcome was an agreement on the minimum which States were to suppress: the exploitation of the prostitution of those over the age of majority; and for those under the age, where consent was irrelevant, all the prostitution of minors.

Finally, that the terms 'abuse of authority', 'fraud', 'threats' and 'violence' - first expressed through the 1910 Convention and now incorporated in the definition of trafficking in persons - are the original 'means' elements which along with 'method' and 'purpose' constitute what

\footnotetext{
80 Note, the information from the United Nations Treaty Series (see following footnote citation) appears to be inaccurate as to the coming into force of the International Convention for the Suppression of the White Slave Traffic, as it sets the date at 18 July 1905, which predates its negotiation. Information regarding the Protocol recording the Deposit of Ratifications of the International Convention for the Suppression of the White Slave Traffic, signed at Paris, May 4, 1910 putting the date of ratification at 8 August 1912 appears accurate. See Foreign Office to Home Office, Enclosure 2 of No. 10, Correspondence respecting the International Conference on Obscene Publications and the 'White Slave Traffic', held in Paris, April and May 1910, House of Commons Parliamentary Papers (United Kingdom), Cd. 6547, p. 44.

81 Information in this paragraph available via the United Nations Treaty Collection, Multilateral Treaties Deposited with the Secretary-General, Chapter VII, Number 10, available at: https://treaties.un.org/.
} 
is today, the three elements of human trafficking. The 1910 International Convention for the Suppression of the White Slave Traffic sheds some light on our understanding of that 'means' element as Article 2 of the 1910 International Convention indicates that the means of 'abuse of authority', 'fraud', 'threats' or 'violence' are, in fact, "means of compulsion". It might be added, that these means of compulsion were the elements which constituted the crime of white slave traffic for those over the age of majority, but were to be considered as aggravating circumstances for the determination of a penalty for those under the age.

To consider the white slave traffic despite its odious terminology, is to provide a further piece of the puzzle of understanding the evolution of the regime which is today human trafficking. Focused as it was on the issue of prostitution, the insight garnered here provide more depth of understanding of the sexual exploitation element of human trafficking. In so doing, it chips away at the ahistorical considerations which have thus far been given to the study of human trafficking within international law and thus provide a bit more grounding, in understanding of the very sources and evolution of what is today known as human trafficking. 


\section{APPENDIX I \\ INTERNATIONAL AGREEMENT FOR THE SUPPRESSION OF THE WHITE SLAVE TRAFFIC}

His Majesty the King of the United Kingdom of Great Britain and Ireland and of the British Dominions beyond the Seas, Emperor of India; His Majesty the German Emperor, King of Prussia, in the name of the German Empire; His Majesty the King of the Belgians; His Majesty the King of Denmark; His Majesty the King of Spain; the President of the French Republic; His Majesty the King of Italy; Her Majesty the Queen of the Netherlands; His Majesty the King of Portugal and of the Algarves; His Majesty the Emperor of all the Russias; His Majesty the King of Sweden and Norway; and the Swiss Federal Council, being desirous of securing to women of full age who have suffered abuse or compulsion, as also to women and girls under age, effective protection against the criminal traffic known as the 'White Slave Traffic' have decided to conclude an Agreement with a view to concerting measures calculated to attain this object, and have appointed as their Plenipotentiaries, that is to say: [List of plenipotentiaries not reproduced here.]

Who, having exchanged their full powers, found in good and due form, have agreed upon the following provisions:

\section{Article 1}

Each of the Contracting Governments undertakes to establish or name some authority charged with the coordination of all information relative to the procuring of women or girls for immoral purposes abroad; this authority shall be empowered to correspond direct with the similar department established in each of the other Contracting States.

\section{Article 2}

Each of the Governments undertakes to have a watch kept, especially in railway stations, ports of embarkation, and en route, for persons in charge of women and girls destined for an immoral life. With this object instructions shall be given to the officials, and all other qualified persons, to obtain, within legal limits, all information likely to lead to the detection of criminal traffic.

The arrival of persons who clearly appear to be the principals, accomplices in, or victims of, such traffic shall be notified, when it occurs, either to the authorities of the place of destination, or to the diplomatic or consular agents interested, or to any other competent authorities.

\section{Article 3}

The Governments undertake, when the case arises, and within legal limits, to have the declarations taken of women or girls of foreign nationality who are prostitutes, in order to establish their identity and civil status, and to discover who has caused them to leave their country. The information obtained shall be communicated to the authorities of the country of origin of the said women and girls, with a view to their eventual repatriation.

The Governments undertake, within legal limits, and as far as can be done, to entrust temporarily, and with a view to their eventual repatriation, the victims of a criminal traffic when destitute to public or private charitable institutions, or to private individuals offering the necessary security. 
The Governments also undertake, within legal limits, and as far as possible, to send back to their country of origin those women and girls who desire it, or who may be claimed by persons exercising authority over them. Repatriation shall only take place after agreement as to identity and nationality, as well as place and date of arrival at the frontiers. Each of the Contracting Countries shall facilitate transit through its territory.

Correspondence relative to repatriation shall be direct as far as possible.

\section{Article 4}

Where the woman or girl to be repatriated cannot herself repay the cost of transfer, and has neither husband, relations, nor guardian to pay for her, the cost of repatriation shall be borne by the country where she is in residence as far as the nearest frontier or port of embarkation in the direction of the country of origin, and by the country of origin as regards the rest.

\section{Article 5}

The provisions of the foregoing Articles 3 and 4 shall not affect any private Conventions existing between the Contracting Governments.

\section{Article 6}

The Contracting Governments undertake, within legal limits, to exercise supervision, as far as possible, over the offices or agencies engaged in finding employment for women or girls abroad.

\section{Article 7}

Non-Signatory States can adhere to the present Agreement. For this purpose they shall notify their intention, through the diplomatic channel, to the French Government, who shall acquaint all the Contracting States.

\section{Article 8}

The present Agreement shall come into force six months after the exchange of ratifications. If one of the Contracting Parties denounces it, this denunciation shall only have effect as regards that party, and that only twelve months after the date of denunciation.

\section{Article 9}

The present Agreement shall be ratified, and the ratifications shall be exchanged, at Paris, with the least possible delay.

IN FAITH WHEREOF the respective plenipotentiaries have signed the present Agreement, and thereunto affixed their seals.

DONE at Paris, the 18th May, 1904, in single copy, which shall be deposited in the archives of the Ministry of Foreign Affairs of the French Republic, and of which one copy, certified correct, shall be sent to each Contracting Party. 


\section{APPENDIX II \\ INTERNATIONAL CONVENTION FOR THE SUPPRESSION OF THE WHITE SLAVE TRAFFIC}

The Sovereigns, Heads of States, and Governments of the Powers hereinafter designated,

Being equally desirous of taking the most effective steps for the suppression of the traffic known as the 'White Slave Traffic', have resolved to conclude a Convention with this object, and a draft thereof having been drawn up at a first Conference which met at Paris from 15 to 25 July 1902, they have appointed their plenipotentiaries, who met at a second Conference at Paris from 18 April to 4 May 1910 and agreed upon the following provisions:

\section{Article 1}

Whoever, in order to gratify the passions of another person, has procured, enticed, or led away, even with her consent, a woman or girl under age, for immoral purposes, shall be punished, notwithstanding that the various acts constituting the offence may have been committed in different countries.

\section{Article 2}

Whoever, in order to gratify the passions of another person, has, by fraud, or by means of violence, threats, abuse of authority, or any other method of compulsion, procured, enticed, or led away a woman or girl over age, for immoral purposes, shall also be punished, notwithstanding that the various acts constituting the offence may have been committed in different countries.

\section{Article 3}

The Contracting Parties whose legislation may not at present be sufficient to deal with the offences contemplated by the two preceding Articles engage to take or to propose to their respective legislatures the necessary steps to punish these offences according to their gravity.

Article 4

The Contracting Parties shall communicate to each other, through the intermediary of the Government of the French Republic, the laws which have already been or may in future be passed in their States relating to the object of the present Convention.

\section{Article 5}

The offences contemplated in Articles 1 and 2 shall, from the day on which the present Convention comes into force, be deemed to be lawfully included in the list of offences for which extradition may be granted in accordance with Conventions already existing between the Contracting Parties.

In cases in which the above provision cannot be made effective without amending existing legislation, the Contracting Parties engage to take or to propose to their respective legislatures the necessary measures. 
The transmission of Letters of Request relating to offences covered by the present Convention shall be effected:

1. Either by direct communication between the judicial authorities;

2. Or through the intermediary of the diplomatic or consular agent of the demanding State in the country to which the demand is addressed. This agent shall forward the Letter of Request direct to the competent judicial authority, and will receive direct from that authority the documents establishing the execution of the Letter of Request;

(in these two cases a copy of the Letter of Request shall always be addressed at the same time to the superior authority of the State to which the demand is addressed);

3. Or through the diplomatic channel.

Each Contracting Party shall make known, by a communication addressed to each of the other Contracting Parties, the method or methods of transmission which it recognises for Letters of Request emanating from that State.

All difficulties which may arise in connection with transmissions effected in cases 1 and 2 of the present Article shall be settled through the diplomatic channel.

In the absence of any different understanding, the Letter of Request must be drawn up either in the language of the State on whom the demand is made or in the language agreed upon between the two States concerned, or else it must be accompanied by a translation made in one of these two languages and duly certified by a diplomatic or consular agent of the demanding State, or by a sworn translator of the State on whom the demand is made.

The execution of the Letters of Request shall not entail repayment of expenses of any kind whatever.

\section{Article 7}

The Contracting Parties undertake to communicate to each other the records of convictions in respect of offences covered by the present Convention where the various acts constituting such offences have been committed in different countries.

These documents shall be forwarded direct by the authorities designated in conformity with Article 1 of the Agreement concluded at Paris on 18 May 1904, to the corresponding authorities of the other Contracting States.

\section{Article 8}

Non-signatory States may accede to the present Convention. For this purpose they shall notify their intention by a declaration which shall be deposited in the archives of the Government of the French Republic. The latter shall communicate a certified copy thereof through the diplomatic channel to each of the Contracting States, and shall inform them at the same time of the date of such deposit. The laws of the acceding State relative to the object of the present Convention shall also be communicated with the said declaration.

Six months after the date of the deposit of the said declaration the Convention shall come into force throughout the extent of the territory of the acceding State, which will thus become a contracting State.

Accession to the Convention shall necessarily entail, without special notification, a concomitant accession to the Agreement of 18 May 1904, in its entirety, which shall take effect, on the same date as the Convention itself, throughout the territory of the acceding State. 
The preceding stipulation does not, however, derogate from Article 7 of the aforementioned Agreement of 18 May 1904, which remains applicable in cases where a State prefers to accede solely to that Agreement.

\section{Article 9}

The present Convention, completed by a Final Protocol which forms an integral part thereof, shall be ratified, and the ratifications shall be deposited at Paris as soon as six of the Contracting States are in a position to do so.

A Protocol recording all deposits of ratifications shall be drawn up, of which a certified copy shall be transmitted through the diplomatic channel to each of the Contracting Parties. The present Convention shall come into force six months after the date of the deposit of the ratifications.

\section{Article 10}

In case of one of the Contracting Parties shall denounce the Convention, such denunciation shall only have effect as regards that State.

The denunciation shall be notified by a declaration which shall be deposited in the archives of the Government of the French Republic. The latter shall communicate a certified copy, through the diplomatic channel, to each of the Contracting States, and shall inform them at the same time of the date of deposit.

Twelve months after that date the Convention shall cease to take effect throughout the territory of the State which has denounced it.

The denunciation of the Convention shall not entail as of right a concomitant denunciation of the Agreement of 18 May 1904, unless it should be so expressly mentioned in the declaration; if not, the Contracting State must, in order to denounce the said Agreement, proceed in conformity with Article 8 of that Agreement.

\section{Article 11}

If a Contracting State desires the present Convention to come into force in one or more of its colonies, possessions, or consular judicial districts, it shall notify its intention to that effect by a declaration which shall be deposited in the archives of the Government of the French Republic. The latter shall communicate a certified copy thereof, through the diplomatic channel, to each of the Contracting States, and shall inform them at the same time of the date of the deposit.

The said declaration as regards colonies, possessions, or consular judicial districts, shall also communicate the laws which have been therein enacted relative to the object of the present Convention. Laws which may in future be enacted therein shall be equally communicated to the Contracting States in conformity with Article 4.

Six months after the date of deposit of the said declaration, the Convention shall come into force in the colonies, possessions, and consular judicial districts mentioned in such declaration.

The demanding State shall make known, by a communication addressed to each of the other Contracting States, which method or methods of transmission it recognizes for Letters of Request destined for those colonies, possessions, or consular judicial districts in respect of which the declaration mentioned in the first paragraph of the present Article shall have been made.

The denunciation of the Convention by one of the Contracting States on behalf of one or more of its colonies, possessions, and consular judicial districts, shall be made under the forms 
and conditions laid down by the first paragraph of the present Article. Such denunciation shall take effect twelve months after the date of the deposit of the declaration thereof in the archives of the Government of the French Republic.

Accession to the Convention by a Contracting State on behalf of one or more of its colonies, possessions, or consular judicial districts shall entail, as of right and without special notification, a concomitant accession to the Agreement of 18 May 1904 in its entirety. The said Agreement shall come into force therein on the same date as the Convention itself. Nevertheless, the denunciation of the Convention by a Contracting State on behalf of one or more of its colonies, possessions, or consular judicial districts shall not necessarily entail a concomitant denunciation of the Agreement of 18 May 1904, unless it should be so expressly mentioned in the declaration; moreover, the declarations which the Powers signatories of the Agreement of 18 May 1904 have been enabled to make respecting the accession of their colonies to the said Agreement are maintained.

Nevertheless, from and after the date of the coming into force of the present Convention, accessions to and denunciations of that Agreement as regards the colonies, possessions, or consular judicial districts of the Contracting States, shall be made in conformity with the stipulations of the present Article.

\section{Article 12}

The present Convention, which shall be dated 4 May 1910, may be signed in Paris up to 31 July following, by the plenipotentiaries of the Powers represented at the second Conference for the Suppression of the "White Slave Traffic".

DONE at Paris, the 4th May, 1910, in a single copy, of which a certified copy shall be communicated to each of the Signatory Powers. 


\section{FINAL PROTOCOL}

At the moment of proceeding to the signature of the Convention of this day, the undersigned plenipotentiaries deem it expedient to indicate the sense in which Articles 1, 2, and 3 of that Convention are to be understood, and in accordance with which it is desirable that the Contracting States, in the exercise of their legislative sovereignty, should provide for the execution of the stipulations agreed upon or for their extension.

A. The stipulations of Articles 1 and 2 are to be considered as a minimum, seeing that it is self-evident that the Contracting Governments remain entirely free to punish other analogous offences, such, for example, as the procuring of women over age, even where neither fraud nor compulsion may have been exercised.

B. As regards the suppression of the offences provided for in Articles 1 and 2, it is fully understood that the words "woman or girl under age", "woman or girl over age" refer to women or girls under or over twenty completed years of age. A law may, nevertheless, fix a more advanced age for protection, on condition that it is the same for women or girls of every nationality.

C. With a view to the suppression of the same offences the law should decree, in every case, a punishment involving loss of liberty, without prejudice to other penalties, principal or accessory; it should also take into account, apart from the age of the victim, the various aggravating circumstances which exist in the case, such as those referred to in Article 2, or the fact that the victim has been in effect delivered over to an immoral life.

D. The case of detention, against her will, of a woman or girl in a brothel could not, in spite of its gravity, be dealt with in the present Convention, seeing that it is governed exclusively by internal legislation.

The present Final Protocol shall be considered as forming an integral part of the Convention of this day, and shall have the same force, validity, and duration.

DONE AND SIGNED at Paris in a single copy, the 4th May, 1910. 